\title{
SMART KANDANG AYAM PETELUR BERBASIS INTERNET OF THINGS UNTUK MENDUKUNG SDGS 2030 (SUSTAINABLE DEVELOPMENT GOALS)
}

\author{
Kurniawan Gigih Lutfi Umam ${ }^{1)}$ \\ 1) Ilmu Komputer, Institute Pertanian Bogor (IPB) \\ Jl. Raya Dramaga, Kampus IPB Dramaga Bogor, Indonesia \\ Email : umam.tekno@gmail.com ${ }^{1)}$
}

\begin{abstract}
Abstrak
Protein merupakan salah satu sumber gizi yang sangat sangat penting bagi manusia. Salah satu sumber protein hewani dapat diperoleh dari telur. Pada peternakan ayam petelur yang perlu diperhatikan diantaranya yaitu pendirian kandang yang jauh dari pemukiman, tapi dekat dengan sumber pakan, air, dan pemasaran.

Selain itu yang perlu diperhatikan yaitu mengenai struktur atau desain kandang, bahan kandang yang dipakai, memperhatikan sanitasi, sirkulasi udara, suhu pada kandang, kapasitas yang baik untuk jumlah ternak yang dihuni didalamnya. Untuk membantu terwujudnya $S D G$ 's dalam penyediaan pangan sumber protein hewani asal ternak maka dibuatlah sebuah inovasi baru di bidang peternakan ayam petelur untuk membantu peningkatan produktifitas hasil peternakan yang lebih baik. Dengan teknologi Internet of Things yang dapat membantu peternak dan mampu membantu melakukan inovasi dalam proses beterbak yang lebih baik untuk mempertahankan dan meningkatkan produktifitas telur pada peternakan di Indonesia. kandang ini memiliki kelebihan yaitu mampu memberikan makan secara otomatis, mengontrol volume air minum, mengontrol suhu kandang, mengontrol pencahayaan dan melakukan penyemprotan desinfeksi secara otomatis dengan menggunakan smartphone.
\end{abstract}

Dengan adanya teknologi ini diharapkan mampu menjadi inovasi dan strategi baru untuk memecahkan permasalahan di dunia peternakan khususnya dalam penyediaan pangan sumber protein hewani asal ternak (Telur) dan dapat membantu terwujudnya $S D G$ 's 2030.

Kata kunci: SDG's 2030, Internet of Things, Ternak, Ayam Petelur, Protein,Telur, Protein Hewani, Gizi, Mengontrol.

\section{Pendahuluan}

SDGs (Sustainable Development Goals) adalah sebuah program pembangunan berkelanjutan dimana didalamnya terdapat 17 tujuan di dalamnya dengan 169 target yang terukur dengan tenggat waktu yang di tentukan. Program ini merupakan agenda pembangunan dunia yang bertujuan untuk kesejahteraan manusian dan planet bumi. Mulai tahun 2016, Tujuan Pembangunan Berkelanjutan (SDGs) 2015-2030 secara resmi menggantikan Tujuan Pembangunan Milennium (MDGs) 2000-2015. Protein merupakan salah satu sumber gizi yang sangat sangat penting bagi manusia. Berdasarkan manfaatnya, protein terbukti sebagai salah satu zat gizi yang penting bagi tumbuh kembang anak, pembentukan otot, dan pencegahan berbagai penyakit. Sayangnya, sebanyak 37 persen penduduk Indonesia masih kekurangan asupan protein. Sesuai standar nasional, konsumsi protein per hari per kapita ditetapkan 55 g yang terdiri dari $80 \%$ protein nabati dan $20 \%$ protein hewani. Hal itu berarti target konsumsi protein hewani sekitar $11 \mathrm{~g} /$ hari/perkapita. Namun yang terjadi, konsumsi protein hewani penduduk Indonesia baru memenuhi 4,7 g/hari/perkapita, jauh lebih rendah dibanding Malaysia, Thailand dan Filipina. Pada 2015, konsumsi telur per kapita nasional mencapai 6,23 kilogram atau 112 butir per tahun, lebih rendah dibandingkan dengan Malaysia yang sudah mencapai 400 butir.

Pada kandang ayam, yang perlu diperhatikan diantaranya yaitu pendirian kandang yang jauh dari pemukiman, tapi dekat dengan sumber pakan, air, dan pemasaran. Selain itu yang perlu diperhatikan yaitu mengenai struktur atau desain kandang, bahan kandang yang dipakai, memperhatikan sanitasi, sirkulasi udara, suhu pada kandang, kapasitas yang baik untuk jumlah ternak yang dihuni didalamnya. Kesehatan ayam juga menjadi salah satu hal penting yang patut di perhatikan sehingga perlu adanya pengontrolan yang berkala terhadap ayam-ayam yang terlihat kurang sehat. Pemberian vitamin pada ayam juga harus rutin diberikan agar ayam tetap sehat dan mampu lebih produktif menghasilkan telur.

Saat melakukan observasi, Penulis mencoba membandingkan jenis kandang yang konvensional dan kandang yang telah menggunakan alat-alat bantu sehingga memudahkan peternak dalam budidaya ayam petelur. Pada jenis kandang yang sudah menggunakan alat bantu yaitu menggunakan alat yang bernama Semi Outomatic Fedeer Layer. Dengan menggunakan alat ini peternak menjadi lebih terbantu dan proses pemberian pakan menjadi lebih mudah dan tidak membutuhkan tenaga yang besar. Namun, masih terdapat kekurangan pada proses perataan makanan pada tempat makan yang telah di sediakan, karena apabila alat tersebut berhenti terlalu lama akan terjadi penumpukan makanan. Sehingga peternak harus meratakan kembali makanan ayam. Pencahayaan yang kurang baik juga dapat menurunkan konsumsi ransum.

Proses desinfeksi penyemprotan untuk kesehatan ayam, saat ini masih dilakukan dengan waktu yang tidak sesuai dengan ketentuan yang seharusnya dilakuka. Dengan demikian, populasi virus dalam kandang dapat 
turun sekitar 30\%. Suhu merupakan salah satu faktor yang mempengaruhi hasil produksi telur. Sebagian besar peternak ayam petelur tidak memperhatikan suhu pada kandang. Seharusnya, suhu pada kandang ayam di sesuaikan dengan umur ayam untuk menghasilkan telur yang optimal. Salah satu tantangan dan hambatan dalam usaha peternakan ayam petelur adalah manajemen pemeliharaan kesehatan yang lemah (Abidin, 2003). Selain itu recording data peternakan juga sangat di perlukan guna mengetahui perkembangan maupun penurunan hasil ternak dan yang menyebabkan hal tersebut terjadi. Namun, tidak semua peternakan memiliki sistem recording data peternakan, pada peternakan yang penulis kunjungi, proses recording datanya pun masih manual dan belum memiliki sistem khusus untuk melakukan recording data peternakan yang mampu berintegrasi.

Saat ini proses integrasi data sudah dipermudah dengan adalah teknologi internet. APJII (Asosiasi Penyelenggara Jasa Internet Indonesia) telah mengumumkan hasil survei Data Statistik Pengguna Internet Indonesia tahun 2016. Jumlah pengguna Internet di Indonesia tahun 2016 adalah 132,7 juta user atau sekitar $51,5 \%$ dari total jumlah penduduk Indonesia sebesar 256,2 juta. Pengguna internet terbanyak ada di pulau Jawa dengan total pengguna 86.339.350 user atau sekitar $65 \%$ dari total penggunan Internet. Jika dibandingkan penggunana Internet Indonesia pada tahun 2014 sebesar 88,1 juta user, maka terjadi kenaikkan sebesar 44,6 juta dalam waktu 2 tahun (2014 - 2016). Sehingga dapat membatu perkembangan Internet of Things. Internet of Things (IoT) adalah sebuah konsep/skenario dimana suatu objek yang memiliki kemampuan untuk mentransfer data melalui jaringan tanpa memerlukan interaksi manusia ke manusia atau manusia ke komputer.

Untuk membantu terwujudnya SDG's dalam penyediaan pangan sumber protein hewani asal ternak maka dibuatlah sebuah inovasi baru di bidang peternakan ayam petelur untuk membantu peningkatan produktifitas hasil peternakan yang lebih baik. Oleh karena itu, Penulis merancang sebuah kandang cerdas dengan teknologi Internet of Things yang dapat membantu peternak dan mampu membantu melakukan perbaikan dan inovasi kandang yang lebih baik untuk mempertahankan dan meningkatkan produktifitas telur pada peternakan di Indonesia. kandang ini memiliki kelebihan yaitu mampu memberikan makan secara otomatis, mengontrol volume air minum, mengontrol suhu kandang, kelembapan kandang dan melakukan penyemprotan desinfeksi secara otomatis dengan menggunakan smartphone. Dengan adanya teknologi ini diharapkan mampu menjadi inovasi dan strategi baru untuk memecahkan permasalahan di dunia peternakan khususnya dalam penyediaan pangan sumber protein hewani asal ternak (Telur) dan dapat membantu terwujudnya SDG's 2030.

\section{Pembahasan}

Peneliti melakukan penelitian tentang Smart Kandang Ayam Petelur berbasis Internet of Things. Tempat penelitian di lampung selatan yaitu kandang ayam petelur dengan kapasitas ayam 15.000 ekor ayam dengan dibagi perkandang berjumlah 5000 ekor ayam dan 1600 ekor ayam serta sistem kandang baterai serta dengan 3 tingkatan, dengan ukuran Panjang $40 \mathrm{~cm}$, Lebar $40 \mathrm{~cm}$, Tinggi Depan $37 \mathrm{~cm}$, Tinggi Belakang $30 \mathrm{~cm}$ dan besar kandang $588 \mathrm{~m}^{2}$. Setelah itu peneliti membuat prototype sebuah kandang yang didesign menyerupai kandang ayam hanya saja prototype ini dibuat untuk satu baris makan ayam dan hanya satu tingkatan.
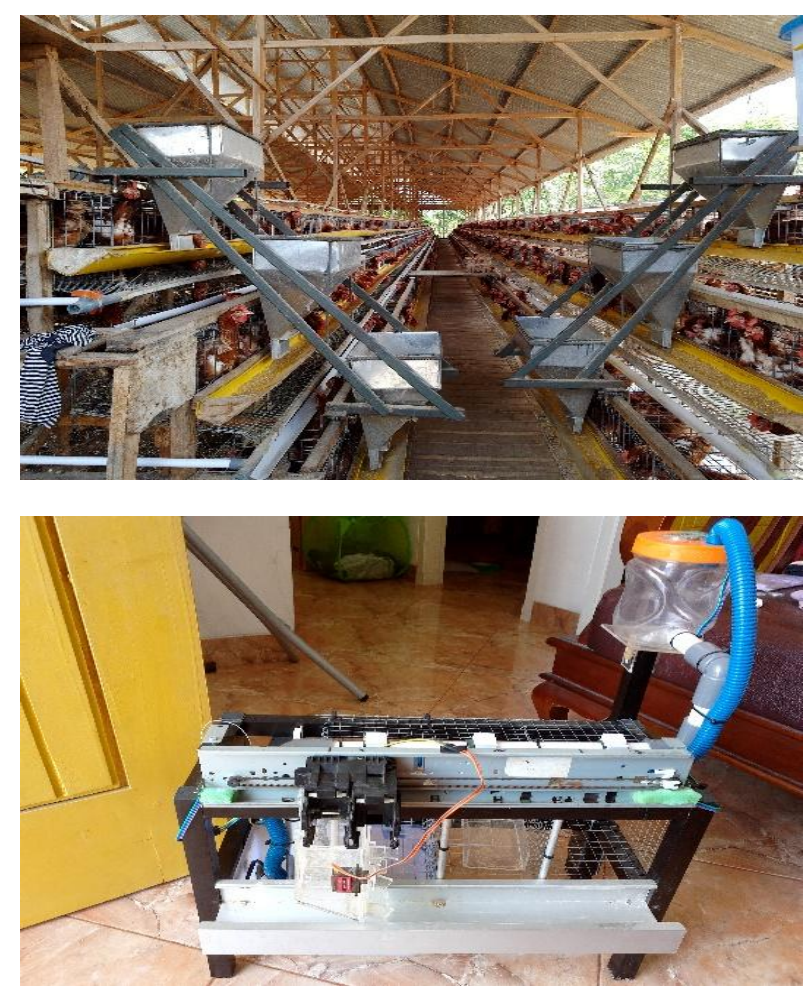

Gambar 1. Implementasi Kandang Cerdas

\subsection{Implementasi Sistem}

Pada sistem kandang ini menggunakan beberapa sensor yaitu sensor Ultrasonic, Sensor DHT 22, relay, Node MCU, Pompa DC, Motor DC serta Motor Servo. Dari sensor DHT 22, Ultrasonic akan mendapatkan data yang akan diterima oleh Node MCU setelah itu Node MCU akan mengirimkan data tersebut ke Firebase dimana Firebase merukan server dari kandang cerdas ini kemudian data yang terdapat pada server akan diambil oleh smartphone yang akan ditampilkan di smartphone dan dapat dimonitoring oleh peternak. Kemudian jika peternak melakukan action berupa pemberian pakan, penyemprotan anti bakteri atau pengisian tower air minum maka data tersebut akan dikirim kan keserver Firebase yang nantinya data tersebut akan diambil oleh Node MCU setelah data terambil maka Node MCU akan memberikan perintah kepada Motor Servo, Pompa DC sesuai dengan action peternak. 


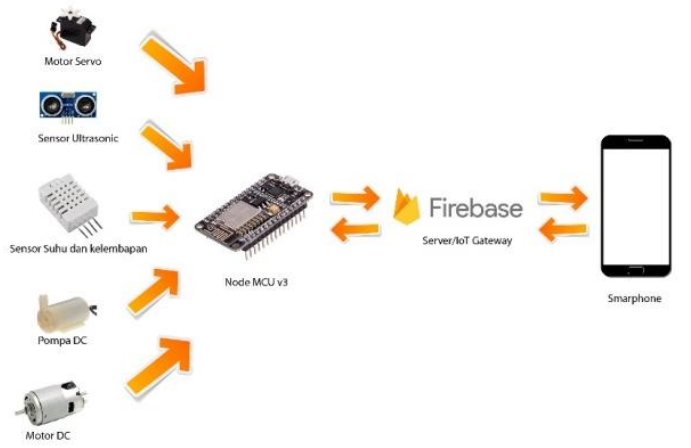

Gambar 2. Implementasi System

\subsection{Pengujian Alat}

Peneliti melakukan pengujian dengan pengujian RealTime system yang dimana pengujian Real-Time system adalah pengujian yang menggunakan Parameter Waktu dan akan menghitung delay proses pada saat alat menggambil data keserver dan smartphone mengambil data keserver dengan menggunakan aplikasi postman untuk melakukan testing. Adapun yang di uji adalah link yang menuju keserver dan akan menghasilkan waktu delay pengambilan data dan pengiriman data yang akan diuji dengan 3 provider yaitu Indosat, Telkomsel, Smartfren. Adapun link yang digunakan adalah:

Digunakan untuk menguji waktu pengambilan data dari alat ke firebase:

http://toko-kirin.pe.hu/GET.php?ref=https://kandangpintar.firebaseio.com/\&auth=SBV6pjZiGfQH1J93wScQ scrRYSDb0Oam35fDciJW\&path=/.

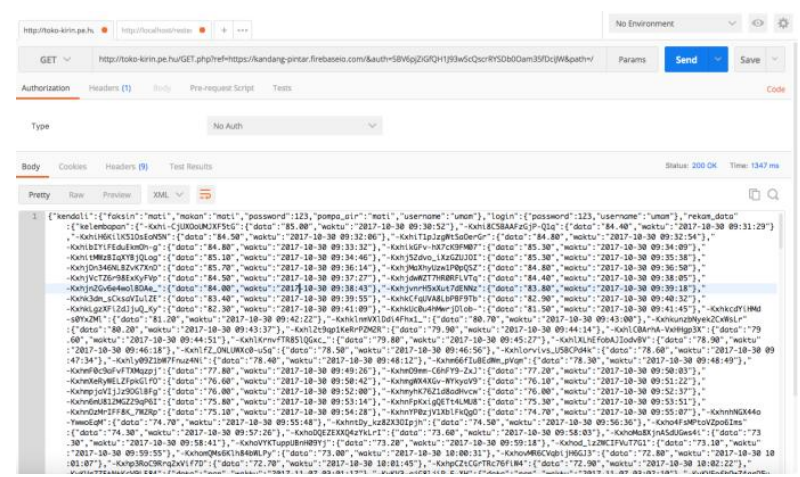

Gambar 3. Postman pengambilan data

Dapat dilihat pada gambar 3 adalah tampilan pada aplikasi postman untuk menguji yang dimana terdapat data yang dapat diambil dari server dan terdapat status ok yang artinya berhasil mengambil data serta terdapat time yang dimana itu adalah waktu delay dalam pengambilan data tersebut.

Digunakan untuk menguji waktu pengambilan data dari handphone ke firebase: https://kandangpintar.firebaseio.com/.json?auth=SBV6pjZiGfQH1J93w ScQscrRYSDb0Oam35fDciJW

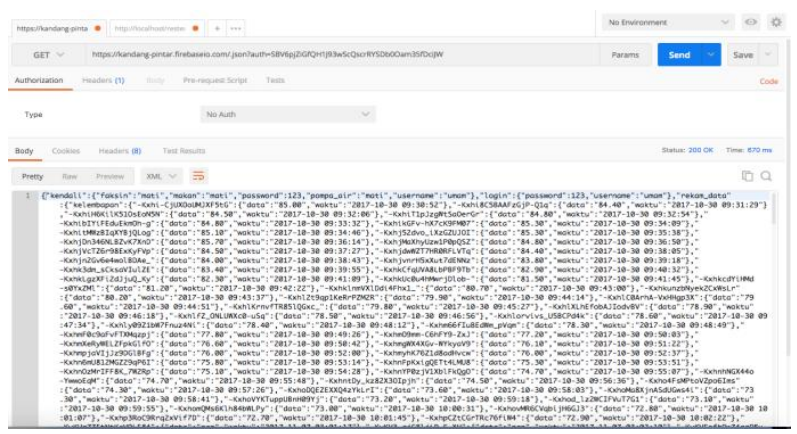

Gambar 4. Postman pengambilan data

Dapat dilihat pada gambar 4 adalah tampilan pada aplikasi postman untuk menguji yang dimana terdapat data yang dapat diambil dari server dan terdapat status ok yang artinya berhasil mengambil data serta terdapat time yang dimana itu adalah waktu delay dalam pengambilan data tersebut.

\subsubsection{Jaringan 4G}

\subsubsection{Smartfren}

Pengujian menggunakan provider smartfren dengan melakukan pengambilan data sebanyak 10 kali diapatkan data sebagai berikut:

Tabel 1. Pengujian dengan Provider Smartfren dari Hp ke Firebase

\begin{tabular}{|c|c|c|c|c|}
\hline \multicolumn{5}{|c|}{ Dari Hp ke Firebase } \\
\hline No & $\begin{array}{c}\text { Ping } \\
(\mathrm{ms})\end{array}$ & $\begin{array}{c}\text { Download } \\
(\mathrm{Mbps})\end{array}$ & $\begin{array}{c}\text { Upload } \\
(\mathrm{Mbps})\end{array}$ & $\begin{array}{c}\text { Delay } \\
(\mathrm{ms})\end{array}$ \\
\hline $\mathbf{1}$ & 25 & 7.36 & 5.24 & 342 \\
\hline $\mathbf{2}$ & 25 & 7.36 & 5.24 & 304 \\
\hline $\mathbf{3}$ & 25 & 7.36 & 5.24 & 286 \\
\hline $\mathbf{4}$ & 25 & 7.36 & 5.24 & 279 \\
\hline $\mathbf{5}$ & 25 & 7.36 & 5.24 & 290 \\
\hline $\mathbf{6}$ & 25 & 7.36 & 5.24 & 289 \\
\hline $\mathbf{7}$ & 25 & 7.36 & 5.24 & 343 \\
\hline $\mathbf{8}$ & 25 & 7.36 & 5.24 & 275 \\
\hline $\mathbf{9}$ & 25 & 7.36 & 5.24 & 287 \\
\hline $\mathbf{1 0}$ & 25 & 7.36 & 5.24 & 277 \\
\hline & \multicolumn{5}{|c}{ Rata - Rata } \\
\hline
\end{tabular}

Tabel 2. Pengujian dengan Provider Smartfren dari Alat ke Firebase

\begin{tabular}{|c|c|c|c|c|}
\hline \multicolumn{5}{|c|}{ Dari Alat ke firebase } \\
\hline No & Ping (ms) & $\begin{array}{c}\text { Download } \\
(\mathrm{Mbps})\end{array}$ & $\begin{array}{c}\text { Upload } \\
(\mathrm{Mbps})\end{array}$ & $\begin{array}{c}\text { Delay } \\
(\mathrm{ms})\end{array}$ \\
\hline $\mathbf{1}$ & 25 & 7.36 & 5.24 & 958 \\
\hline $\mathbf{2}$ & 25 & 7.36 & 5.24 & 814 \\
\hline $\mathbf{3}$ & 25 & 7.36 & 5.24 & 1186 \\
\hline $\mathbf{4}$ & 25 & 7.36 & 5.24 & 835 \\
\hline $\mathbf{5}$ & 25 & 7.36 & 5.24 & 555 \\
\hline $\mathbf{6}$ & 25 & 7.36 & 5.24 & 1090 \\
\hline $\mathbf{7}$ & 25 & 7.36 & 5.24 & 604 \\
\hline $\mathbf{8}$ & 25 & 7.36 & 5.24 & 900 \\
\hline $\mathbf{9}$ & 25 & 7.36 & 5.24 & 604 \\
\hline
\end{tabular}




\begin{tabular}{|c|c|c|c|c|}
\hline \multicolumn{5}{|c|}{ Dari Alat ke firebase } \\
\hline No & Ping (ms) & Download & Upload & Delay \\
\hline $\mathbf{1 0}$ & 25 & 7.36 & 5.24 & 931 \\
\hline \multicolumn{5}{|c|}{ Rata - Rata } \\
\hline
\end{tabular}

\subsubsection{Indosat}

Pengujian menggunakan provider Indosat dengan melakukan pengambilan data sebanyak 10 kali diapatkan data sebagai berikut :

Tabel 3. Pengujian dengan Provider Indosat dari HP ke Firebase

\begin{tabular}{|c|c|c|c|c|}
\hline \multicolumn{5}{|c|}{ Dari Hp ke Firebase } \\
\hline No & $\begin{array}{c}\text { Ping } \\
(\mathrm{ms})\end{array}$ & $\begin{array}{c}\text { Download } \\
(\mathrm{Mbps})\end{array}$ & $\begin{array}{c}\text { Upload } \\
(\mathrm{Mbps})\end{array}$ & $\begin{array}{c}\text { Delay } \\
(\mathrm{ms})\end{array}$ \\
\hline 1 & 37 & 4.15 & 7.22 & 340 \\
\hline $\mathbf{2}$ & 37 & 4.15 & 7.22 & 342 \\
\hline $\mathbf{3}$ & 37 & 4.15 & 7.22 & 332 \\
\hline $\mathbf{4}$ & 37 & 4.15 & 7.22 & 314 \\
\hline $\mathbf{5}$ & 37 & 4.15 & 7.22 & 314 \\
\hline $\mathbf{6}$ & 37 & 4.15 & 7.22 & 319 \\
\hline $\mathbf{7}$ & 37 & 4.15 & 7.22 & 302 \\
\hline $\mathbf{8}$ & 37 & 4.15 & 7.22 & 299 \\
\hline $\mathbf{9}$ & 37 & 4.15 & 7.22 & 343 \\
\hline $\mathbf{1 0}$ & 37 & 4.15 & 7.22 & 447 \\
\hline \multicolumn{5}{|c|}{ Rata - rata } \\
\hline
\end{tabular}

Tabel 4. Pengujian dengan Provider Indosat dari Alat ke Firebase

\begin{tabular}{|c|c|c|c|c|}
\hline \multicolumn{5}{|c|}{ Dari Alat ke Firebase } \\
\hline No & $\begin{array}{c}\text { Ping } \\
(\mathrm{ms})\end{array}$ & $\begin{array}{c}\text { Download } \\
(\mathrm{Mbps})\end{array}$ & $\begin{array}{c}\text { Upload } \\
(\mathrm{Mbps})\end{array}$ & $\begin{array}{c}\text { Delay } \\
(\mathrm{ms})\end{array}$ \\
\hline 1 & 37 & 4.15 & 7.22 & 840 \\
\hline 2 & 37 & 4.15 & 7.22 & 1026 \\
\hline 3 & 37 & 4.15 & 7.22 & 980 \\
\hline 4 & 37 & 4.15 & 7.22 & 1090 \\
\hline 5 & 37 & 4.15 & 7.22 & 948 \\
\hline 6 & 37 & 4.15 & 7.22 & 2088 \\
\hline 7 & 37 & 4.15 & 7.22 & 943 \\
\hline 8 & 37 & 4.15 & 7.22 & 926 \\
\hline 9 & 37 & 4.15 & 7.22 & 1134 \\
\hline 10 & 37 & 4.15 & 7.22 & 2078 \\
\hline \multicolumn{5}{|c|}{ Rata - rata } \\
\hline
\end{tabular}

\subsubsection{Telkomsel}

Pengujian menggunakan provider Telkomsel dengan melakukan pengambilan data sebanyak 10 kali diapatkan data sebagai berikut:
Tabel 5. Pengujian dengan Provider Telkomsel dari HP ke Firebase

\begin{tabular}{|c|c|c|c|c|}
\hline \multicolumn{5}{|c|}{ Dari Hp ke Firebase } \\
\hline No & $\begin{array}{c}\text { Ping } \\
(\mathrm{ms})\end{array}$ & $\begin{array}{c}\text { Download } \\
(\mathrm{Mbps})\end{array}$ & $\begin{array}{c}\text { Upload } \\
(\mathrm{Mbps})\end{array}$ & $\begin{array}{c}\text { Delay } \\
(\mathrm{ms})\end{array}$ \\
\hline $\mathbf{1}$ & 62 & 8.8 & 5.23 & 1098 \\
\hline $\mathbf{2}$ & 62 & 8.8 & 5.23 & 317 \\
\hline $\mathbf{3}$ & 62 & 8.8 & 5.23 & 370 \\
\hline $\mathbf{4}$ & 62 & 8.8 & 5.23 & 358 \\
\hline $\mathbf{5}$ & 62 & 8.8 & 5.23 & 327 \\
\hline $\mathbf{6}$ & 62 & 8.8 & 5.23 & 487 \\
\hline $\mathbf{7}$ & 62 & 8.8 & 5.23 & 348 \\
\hline $\mathbf{8}$ & 62 & 8.8 & 5.23 & 428 \\
\hline $\mathbf{9}$ & 62 & 8.8 & 5.23 & 348 \\
\hline $\mathbf{1 0}$ & 62 & 8.8 & 5.23 & 327 \\
\hline \multicolumn{5}{|c|}{ Rata - rata } \\
\hline
\end{tabular}

Tabel 6. Pengujian dengan Provider Telkomsel dari Alat ke Firebase

\begin{tabular}{|c|c|c|c|c|}
\hline \multicolumn{5}{|c|}{ Dari Alat ke Firebase } \\
\hline No & $\begin{array}{c}\text { Ping } \\
(\mathrm{ms})\end{array}$ & $\begin{array}{c}\text { Download } \\
(\mathrm{Mbps})\end{array}$ & $\begin{array}{c}\text { Upload } \\
(\mathrm{Mbps})\end{array}$ & $\begin{array}{c}\text { Delay } \\
(\mathrm{ms})\end{array}$ \\
\hline 1 & 62 & 8.8 & 5.23 & 1274 \\
\hline 2 & 62 & 8.8 & 5.23 & 1107 \\
\hline 3 & 62 & 8.8 & 5.23 & 1459 \\
\hline 4 & 62 & 8.8 & 5.23 & 1217 \\
\hline 5 & 62 & 8.8 & 5.23 & 955 \\
\hline 6 & 62 & 8.8 & 5.23 & 1406 \\
\hline 7 & 62 & 8.8 & 5.23 & 1009 \\
\hline 8 & 62 & 8.8 & 5.23 & 1244 \\
\hline 9 & 62 & 8.8 & 5.23 & 1112 \\
\hline 10 & 62 & 8.8 & 5.23 & 1166 \\
\hline \multicolumn{5}{|c|}{ Rata - rata } \\
\hline
\end{tabular}

\subsubsection{Jaringan 3G}

\subsubsection{Indosat}

Pengujian menggunakan provider Indosat dengan melakukan pengambilan data sebanyak 10 kali diapatkan data sebagai berikut :

Tabel 7. Pengujian dengan Provider Indosat dari HP ke Firebase

\begin{tabular}{|c|c|c|c|c|}
\hline \multicolumn{5}{|c|}{ Dari Hp ke Firebase } \\
\hline No & $\begin{array}{c}\text { Ping } \\
(\mathrm{ms})\end{array}$ & $\begin{array}{c}\text { Download } \\
(\mathrm{Mbps})\end{array}$ & $\begin{array}{c}\text { Upload } \\
(\mathrm{Mbps})\end{array}$ & $\begin{array}{c}\text { Delay } \\
(\mathrm{ms})\end{array}$ \\
\hline $\mathbf{1}$ & 38 & 1.93 & 1.13 & 5934 \\
\hline $\mathbf{2}$ & 38 & 1.93 & 1.13 & 496 \\
\hline $\mathbf{3}$ & 38 & 1.93 & 1.13 & 3079 \\
\hline $\mathbf{4}$ & 38 & 1.93 & 1.13 & 2837 \\
\hline $\mathbf{5}$ & 38 & 1.93 & 1.13 & 2769 \\
\hline $\mathbf{6}$ & 38 & 1.93 & 1.13 & 1338 \\
\hline $\mathbf{7}$ & 38 & 1.93 & 1.13 & 2046 \\
\hline $\mathbf{8}$ & 38 & 1.93 & 1.13 & 2565 \\
\hline $\mathbf{9}$ & 38 & 1.93 & 1.13 & 365 \\
\hline
\end{tabular}




\begin{tabular}{|c|c|c|c|c|}
\hline \multicolumn{5}{|c|}{ Dari Hp ke Firebase } \\
\hline No & Ping & Download & Upload & Delay \\
\hline $\mathbf{1 0}$ & 38 & 1.93 & 1.13 & 419 \\
\hline \multicolumn{5}{|c|}{ Rata - rata } \\
\hline
\end{tabular}

Tabel 8. Pengujian dengan Provider Indosat dari Alat ke Firebase

\begin{tabular}{|c|c|c|c|c|}
\hline \multicolumn{5}{|c|}{ Dari Alat ke Firebase } \\
\hline No & $\begin{array}{c}\text { Ping } \\
(\mathrm{ms})\end{array}$ & $\begin{array}{c}\text { Download } \\
(\mathrm{Mbps})\end{array}$ & $\begin{array}{c}\text { Upload } \\
(\mathrm{Mbps})\end{array}$ & $\begin{array}{c}\text { Delay } \\
(\mathrm{ms})\end{array}$ \\
\hline 1 & 38 & 1.93 & 1.13 & 897 \\
\hline 2 & 38 & 1.93 & 1.13 & 2067 \\
\hline 3 & 38 & 1.93 & 1.13 & 1178 \\
\hline 4 & 38 & 1.93 & 1.13 & 881 \\
\hline 5 & 38 & 1.93 & 1.13 & 1072 \\
\hline 6 & 38 & 1.93 & 1.13 & 903 \\
\hline 7 & 38 & 1.93 & 1.13 & 1020 \\
\hline 8 & 38 & 1.93 & 1.13 & 1042 \\
\hline 9 & 38 & 1.93 & 1.13 & 4059 \\
\hline 10 & 38 & 1.93 & 1.13 & 1138 \\
\hline \multicolumn{5}{|c|}{ Rata - rata } \\
\hline
\end{tabular}

\subsubsection{Telkomsel}

Pengujian menggunakan provider Telkomsel dengan melakukan pengambilan data sebanyak 10 kali diapatkan data sebagai berikut :

Tabel 9. Pengujian dengan Provider Telkomsel dari HP ke Firebase

\begin{tabular}{|c|c|c|c|c|}
\hline \multicolumn{5}{|c|}{ Dari Hp ke Firebase } \\
\hline No & $\begin{array}{c}\text { Ping } \\
(\mathrm{ms})\end{array}$ & $\begin{array}{c}\text { Download } \\
(\mathrm{Mbps})\end{array}$ & $\begin{array}{c}\text { Upload } \\
(\mathrm{Mbps})\end{array}$ & $\begin{array}{c}\text { Delay } \\
(\mathrm{ms})\end{array}$ \\
\hline $\mathbf{1}$ & 102 & 2 & 3.57 & 937 \\
\hline $\mathbf{2}$ & 102 & 2 & 3.57 & 588 \\
\hline $\mathbf{3}$ & 102 & 2 & 3.57 & 670 \\
\hline $\mathbf{4}$ & 102 & 2 & 3.57 & 657 \\
\hline $\mathbf{5}$ & 102 & 2 & 3.57 & 496 \\
\hline $\mathbf{6}$ & 102 & 2 & 3.57 & 339 \\
\hline $\mathbf{7}$ & 102 & 2 & 3.57 & 381 \\
\hline $\mathbf{8}$ & 102 & 2 & 3.57 & 435 \\
\hline $\mathbf{9}$ & 102 & 2 & 3.57 & 399 \\
\hline $\mathbf{1 0}$ & 102 & 2 & 3.57 & 365 \\
\hline \multicolumn{5}{|c|}{ Rata - rata } \\
\hline
\end{tabular}

Tabel 10. Pengujian dengan Provider Telkomsel dari Alat ke Firebase

\begin{tabular}{|c|c|c|c|c|}
\hline \multicolumn{5}{|c|}{ Dari Alat ke Firebase } \\
\hline No & $\begin{array}{c}\text { Ping } \\
(\mathrm{ms})\end{array}$ & $\begin{array}{c}\text { Download } \\
(\mathrm{Mbps})\end{array}$ & $\begin{array}{c}\text { Upload } \\
(\mathrm{Mbps})\end{array}$ & $\begin{array}{c}\text { Delay } \\
(\mathrm{ms})\end{array}$ \\
\hline 1 & 102 & 2 & 3.57 & 934 \\
\hline 2 & 102 & 2 & 3.57 & 945 \\
\hline 3 & 102 & 2 & 3.57 & 1094 \\
\hline 4 & 102 & 2 & 3.57 & 934 \\
\hline 5 & 102 & 2 & 3.57 & 895 \\
\hline
\end{tabular}

\begin{tabular}{|c|c|c|c|c|}
\hline \multicolumn{5}{|c|}{ Dari Alat ke Firebase } \\
\hline No & Ping & Download & Upload & Delay \\
\hline 6 & 102 & 2 & 3.57 & 935 \\
\hline 7 & 102 & 2 & 3.57 & 939 \\
\hline 8 & 102 & 2 & 3.57 & 911 \\
\hline 9 & 102 & 2 & 3.57 & 895 \\
\hline 10 & 102 & 2 & 3.57 & 931 \\
\hline \multicolumn{5}{|c|}{ Rata - rata } \\
\hline
\end{tabular}

Setelah melakukan pengujian dari 3 provider di 2 jaringan yang berbeda yaitu di jaringan 4G dan 3G, maka dapat ditampilkan grafik sebegai berikut :

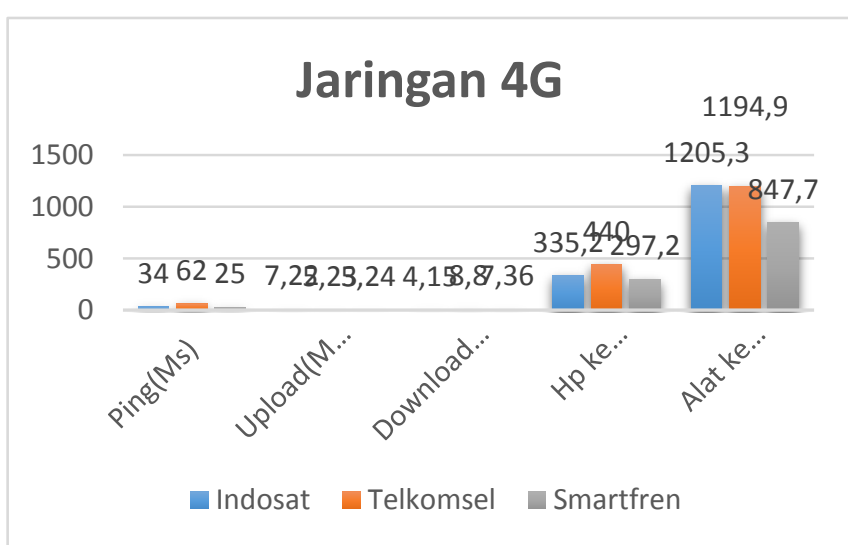

Gambar 5. Grafik Jaringan 4G

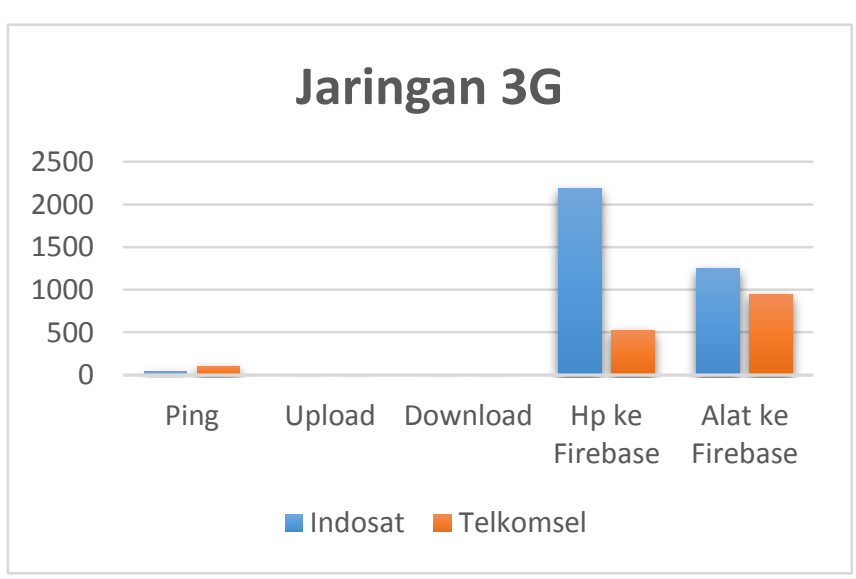

Gambar 6. Grafik Jaringan 3G

\section{Kesimpulan}

Berdasarkan hasil pengujian yang telah dilakukan dapat disimpulkan untuk penerapan internat of things di provinsi lampung dapat berjalan dengan baik baik menggunakan jaringan $4 \mathrm{G}$ maupun $3 \mathrm{G}$, melihat tempat kandang ayam yang harus ditempatkan jauh dari pemukiman mengakibatkan lemahnya jaringan internet yang hanya mendapatkan jaringan $3 \mathrm{G}$, tetapi dengan jaringan $3 \mathrm{G}$ penerapan internet of things sudah dapat diterapkan hanya saja proses pengiriman data yang sedikit membutuhkan waktu. 


\section{Daftar Pustaka}

[1] Marginingtyas, E, Mahmudy, WF \& Indriati 2015, 'Penentuan komposisi pakan ternak untuk memenuhi kebutuhan nutrisi ayam petelur dengan biaya minimum menggunakan algoritma genetika', DORO: Repository Jurnal Mahasiswa PTIIK Universitas Brawijaya, vol. 5, no. 12.

[2] Populasi dan Produksi Peternakan di Indonesia. http://www.pertanian.go.id/

Indikator/tabel-4-pop-prod-nak.pdf

(diakses

Tanggal 30 Maret 2017 Pukul 17.00 WIB)

[3] Populasi Ayam Ras Petelur menurut Provinsi, 2009-2016.

https://www.bps.go.id/linkTableDinamis/view/id/1 031 (Diakses Tanggal 29 Maret 2017 Pukul 11.00 WIB).

[4] Dahlan,Mufid \& Hudi,Nur, Juni 2011, 'Studi Manajemen Perkandangan Ayam Broiler di Dusun Wangket Desa Kaliwates Kecematan Kembangahu Kabupaten Lamongan', Jurnal Ternak, Vol. 02, No. 01.

[5] Peraturan Menteri Pertanian Republik Indonesia Nomor 31/Permentan/OT.140/2/2015.

http://perundangan.pertanian.go.id/admin/file/Perm entan\%20No.31\%20Tahun\%202014\%20Pedoman \%20Budidaya\%20Ayam\%20Petelur.pdf(Diakses Tanggal 29 Maret 2017 Pukul 21.00 WIB).

[6] Marius, Parlindungan \& Anggoro, Sapto, 2016. 'Data Statistik Pengguna Internet di Indonesia', APJII, 2016.

[7] Gondchawar, Nikesh \& Kawitkar. R.S, June 2016, 'IoT based Smart Agriculture', June 2016. International Journal of Advanced Research in Computer and Communication Engineering. Vol.5, Issue 6.

[8] Yurmama, TriFajar. 2009. "Perancangan Software Aplikasi Pervasive Smart Home." Jurnal Seminar Nasional Aplikasi Teknologi Informasi, Yogyakarta. 